\title{
Identity and self-understanding among transgender women in Norway
}

\section{Vigdis Moen*}

Faculty of Medicine and Health Sciences. Department of Public Health and Nursing

Norwegian University of Science and Technology (NTNU)

Email: vigdis.moen@ntnu.no

*corresponding author

\section{Ingvild Aune}

Faculty of Medicine and Health Sciences, Department of Public Health and Nursing

Norwegian University of Science and Technology (NTNU)

Email: ingvild.aune@ntnu.no

\begin{abstract}
Aim: The aim of this study is to gain a deeper understanding of and more knowledge about the experience of transgender women in terms of identity and self-understanding.

Method: Data are collected from six Norwegian adult transgender women who have told their life stories. A narrative analysis is used to analyse the stories of the participants. The narrative focus is on themes relating to identity, selfunderstanding and belonging.
\end{abstract}

Results: The results of the study show that the participants exclusively have a female identity and sense of belonging. Despite this, two of the participants prefer to live as males out of consideration for those in their surroundings. The self-understanding of the informants is expressed in different ways, depending on personality and life experience.

Conclusion: Whether or not one has 'come out of the closet' seems to be important for both identity and self-understanding. The participants who are open about their identity seem more secure than those who are not. The more 
acceptance and recognition they get from the social environment, the more it appears that the women in this study dare to be who they are.

Keywords: gender identity; self-understanding; belonging; coming out; significance of surroundings environment

\section{Introduction}

Transgender people are a diverse population of individuals who do not identify with their gender at birth (Benestad, 2004; Arntzen \& Kahrs, 2013). Transgender identity concerns women and men who masculinise or feminise their bodies with cross-sex hormone treatment and/or gender-confirming surgery (Bouman et al., 2017; Benestad, 2004). The transgender phenomenon is complex, and there is great confusion about the different terms. Most cisgender people, like the authors, are unfamiliar with the words that people in the transgender community use to describe themselves, their experiences and their most pressing issues (Serano, 2016). Transgenderism emerged as a term in 1969 (Ekings \& King, 1996) and has been - and still is - used in different ways. For some, the term is an umbrella term for all types of transgender people, including transsexuals, transvestites, etc. (Ekings \& King, 1996). For others, and especially in the United States, a transgender person is one who lives as the opposite sex without a desire for gender-confirming treatment (Graugaard, 2001). The term transgender may be seen as a postmodern concept; whereas in one sense, gender implies a subjective, social and linguistic understanding of bodily gender, a postmodern understanding is based on a more philosophical perspective (Stryker \& Whittle, 2006; Sanger, 2010; Ansara, 2010; Aizura, 2012). Transgender people experience a gender incongruence, which is a sense of conflict between somatic gender and the psychological component of gender (Van der Ros, 2014). Every human being has a story. For some, the story is more complex than for others. Many transgender people have encountered a number of challenges, such as disclosing their gender identity. Mental suffering, such as anxiety and depression, is not uncommon, and there is a relatively high risk of suicide (Hansen, 2001; Winzer \& Bostrøm, 2007; The Norwegian Health Directorate, 2015; Bouman et al., 2017).

The term identity in this article refers to gender identity. The definition of the term gender identity is the subjective and individual experience related to gender. This is a feeling of being unique and independent and a perception about a permanent connection between the person you are on one hand and body experience, body image and life experiences on the other (Almås, 2004; The Norwegian Health Directorate, 2015; Almås \& Benestad, 2017; Van der 
Ros, 2016). The term self-understanding may to some extent include the identity concept. However, self-understanding can be more directly linked to self-image and how one understands oneself as a human being. How one understands oneself can be conditioned by the response from the surrounding environment to a larger degree than identity. Who we understand ourselves to be may be very different (Henriksen \& Vetlesen, 2006; Mead et al., 2015; Røkenes \& Hanssen, 2012). It could be to see yourself as part of a social class, a family or a college. In this case, self-understanding is also linked to how the social environment responds to gender and gender belonging. The aim of this study is to gain a deeper understanding of and more knowledge about the experience of transgender women in terms of identity and self-understanding.

\section{Methods}

\section{Participants}

This study is based on personal and, in some cases, intimate topics. Therefore, the selection of participants is based on accessibility. Only women wanted to participate and did so on a voluntary basis. The sample consists of six transgender women of different ages and in different stages of life. The variation in age and life cycle is an important factor when exploring possible differences. A sample that is too homogeneous makes it more difficult to discover nuances that could generate new knowledge or questions (Malterud, 2011). The researcher (VM) recruited the informants from transgender interest groups. There was no relationship between the researcher and the informants. The inclusion criterium was that each participant had to be a transgender person of adult age with no psychiatric diagnosis besides their prospective transsexualism, according to the tenth revision of the International Statistical Classification of Diseases and Related Health Problems (ICD-10) (World Health Organization, 2016). The participants received written and oral information about the aim of the study and the terms of confidentiality. They subsequently gave written informed consent.

All the participants live in the same city, but come from different places in Norway. All the names used in the study are pseudonyms. The youngest participant, Siri (24), has a job in addition to studying to become a primary school teacher. She is considering taking a break from her studies until she has finished the gender-confirming treatment. She is single and has a few good friends. Her contact with her parents and brother, who live elsewhere in the country, is good. Karin (44) is a nurse and works full time in the healthcare sector. She is single and still in the closet, which means that she officially lives 
as male and has not told anyone about her female identity. Outside work, she has a limited social network. She has some contact with her siblings, who live elsewhere in the country. Ingrid (60) is the oldest of the participants. She has finished her gender-confirming treatment and still lives with her wife. She has good contact with her children, other relatives and friends. She is partially disabled due to heart disease, and works in a print shop. Turid (51) is a trained mason, but due to health problems has been on sick leave over the last year. She is married for the second time and has children from her first and second marriages. She has a good social network, and prefers an androgynous expression. Marianne (50) is an IT graduate. She is now disabled but works a little in a kindergarten. She has finished her gender-confirming treatment, lives in a lesbian relationship and has a son from a previous relationship with whom she stays in regular contact. Apart from this, she has no contact with her family members. Berit (34) is also an IT graduate and works full time. She cohabits with a woman but is still in the closet. She has good contact with family and friends.

\section{Narrative analysis}

A narrative analysis was selected to analyse the life story of the participants. This type of analysis can be conducted in different ways. The approach used in this study is a combination of a thematic analysis (Riessman, 2008) and an analysis of contents (Johansson, 2005). Before starting the data collection, a list of factors the researcher wanted to address was compiled. The main factors were childhood and adolescence, point of coming out, family matters and sexuality. In this way, the participants revealed their stories through dialogue with the researcher and not in a monologue. When working through the written data, the text was classified according to key themes, such as 'gender identity'. This is what Riessman (2008) calls thematic analysis. Johansson (2005) uses the term partial content, which means that one defines certain categories and analyses the content (i.e. content analysis). This is commonly used in the social sciences, such as sociology. The data is derived from the experiences and situations of the informants, and as analysts the researchers developed the thematic categories, presented in Figure 1. 


\begin{tabular}{|c|c|c|c|c|c|c|}
\hline $\begin{array}{l}\text { Informant } \rightarrow \\
\text { Code } \downarrow\end{array}$ & $\begin{array}{l}\text { 'Siri' } \\
24 \\
\text { years } \\
\text { old }\end{array}$ & $\begin{array}{l}\text { ‘Karin' } \\
44 \text { years } \\
\text { old }\end{array}$ & $\begin{array}{l}\text { 'Ingrid' } \\
60 \\
\text { years } \\
\text { old }\end{array}$ & $\begin{array}{l}\text { 'Turid' } \\
51 \\
\text { years } \\
\text { old }\end{array}$ & $\begin{array}{l}\text { 'Marianne' } \\
50 \text { years } \\
\text { old }\end{array}$ & $\begin{array}{l}\text { 'Berit' } \\
34 \text { years } \\
\text { old }\end{array}$ \\
\hline $\begin{array}{l}\text { Gender } \\
\text { identity }\end{array}$ & Female & Female & Female & Female & Female & Female \\
\hline $\begin{array}{l}\text { Self- } \\
\text { understanding }\end{array}$ & $\begin{array}{l}\text { 'I just } \\
\text { want to } \\
\text { be } \\
\text { myself' }\end{array}$ & $\begin{array}{l}\text { ‘I wish to } \\
\text { be a real } \\
\text { person’ }\end{array}$ & $\begin{array}{l}\text { 'There } \\
\text { is no } \\
\text { real } \\
\text { stuff' }\end{array}$ & $\begin{array}{l}\text { 'I know } \\
\text { who I } \\
\text { am' }\end{array}$ & $\begin{array}{l}\text { 'Finally I } \\
\text { can be the } \\
\text { person I } \\
\text { have } \\
\text { always } \\
\text { been' }\end{array}$ & $\begin{array}{l}\text { 'I want } \\
\text { to } \\
\text { repress } \\
\text { who I } \\
\text { am' }\end{array}$ \\
\hline Coming out & $\begin{array}{l}\text { Has } \\
\text { come } \\
\text { out }\end{array}$ & $\begin{array}{l}\text { Still in } \\
\text { the } \\
\text { closet }\end{array}$ & $\begin{array}{l}\text { Has } \\
\text { come } \\
\text { out }\end{array}$ & $\begin{array}{l}\text { Has } \\
\text { come } \\
\text { out }\end{array}$ & $\begin{array}{l}\text { Has come } \\
\text { out }\end{array}$ & $\begin{array}{l}\text { Still in } \\
\text { the } \\
\text { closet }\end{array}$ \\
\hline Belonging & $\begin{array}{l}\text { Belongs } \\
\text { to the } \\
\text { female } \\
\text { gender }\end{array}$ & $\begin{array}{l}\text { Feels } \\
\text { like a } \\
\text { female, } \\
\text { chooses } \\
\text { the male } \\
\text { category }\end{array}$ & $\begin{array}{l}\text { Belongs } \\
\text { to the } \\
\text { female } \\
\text { gender }\end{array}$ & $\begin{array}{l}\text { Belongs } \\
\text { to the } \\
\text { female } \\
\text { gender }\end{array}$ & $\begin{array}{l}\text { Belongs } \\
\text { to the } \\
\text { female } \\
\text { gender }\end{array}$ & $\begin{array}{l}\text { Feels } \\
\text { like a } \\
\text { female, } \\
\text { chooses } \\
\text { the male } \\
\text { category }\end{array}$ \\
\hline
\end{tabular}

Figure 1

\section{Ethics}

The Norwegian Social Science Data Services approved the research project (NSD, project no. 17831). The participants gave written consent. They were informed that the study will not have any consequences for possible hormonal or surgical treatment. In this respect, the participants were not patients, and the study did not require subsequent approval by the ethics committee. No medical intervention occurred, and only discussions about 'who you are' took place. The authors do not consider transgenderism a pathologic phenomenon. Transgender people are human beings who face existential issues (Henriksen \& Vetlesen, 2000; Johannessen, Kokkersvold, \& Vedeler, 1994; Moen, 2008; 
Moen, 2010), like other people who encounter challenges in life. However, the challenges of transgender people can affect their mental health. Therefore, it was important that the participants did not have a psychiatric diagnosis in addition to their gender identity challenges. The names used in the study are pseudonyms.

Professionals who deal with controversial issues, including those related to sexology, would be happy to give a voice to groups that usually do not get any attention in society. Transgender people are vulnerable, and the results of this study may be used in the public debate and in policymaking to benefit this particular group. Researchers ought to reflect on their own role as interviewers, listeners or interlocutors. They should be aware of the importance of both verbal and nonverbal communication, as well as the associated aspects of control and power. In this context, Johansson (2005) points out that both reports and analyses are marked by researchers' pre-understanding and professional background and that analyses of conversations should be considered. In their analysis, the authors of the current study have made an effort put aside hypotheses, preconceptions and the theoretical framework of reference.

\section{Results and discussion}

\section{Identity and self-understanding}

The participants in this study identify themselves as women. However, there are differences with regard to self-understanding, how they understand themselves as human beings and how they choose to discuss their gender. Kuper et al. (2012) state that understanding the self-defined identities of transgender individuals is important when judging how the self is represented in relation to others, for instance. The narratives of the transgender women in this study start in their early childhood; without exception they all have had transgendered feelings and experiences as long as they can remember. Although their childhood memories can be interpreted as constructed narratives (Lundby, 1998; Monk, 2007; White, 2006), they should still be considered relevant in the context of identity questions (Hines, 2007). The youngest participant, Siri (24), begins her narrative in this way:

I can remember fragments even when I was about 3 years old ... and when I was 5 I had ideas about how I wished to be dressed. In school I identified with the girls, and I wanted the same hair style and clothes as them. I didn't think clearly about being a girl at that time ... I got conscious little by little, and when I was about 11 years old, I was very conscious about it. I also 
thought I was lucky not to have a sister. If I had, I would all the time be reminded of what I couldn't be ...

Karin is 44 years old. She has kept her female identity secret her whole life. She grew up in a Christian home, which may have influenced the development of her identity and self-understanding and may be a contributing factor to her still being in the closet. The hidden cross-dressing started when she was about 5 years old and continued during her adolescence. She states that:

I was cross-dressing when I was home alone. I used the opportunity to borrow my sister's clothes. It felt both funny and comfortable. But afterwards I felt ashamed and got a sense of guilt. I thought it was sinful and that the devil had tempted me. If I prayed to God, the need to crossdress might disappear ...

The other participants in the study had similar childhood experiences. For all human beings, identity develops and is affected by factors such as gender, sexuality, age, cultural and social belonging (Almås \& Benestad, 2017; Hines, 2007; Røkenes \& Hansen, 2012). From a narrative perspective, it is essential to return to childhood experiences and attempt to redefine the self (Monk, 2007). This is because one is interested in telling a new story about childhood, resurrecting abilities or talents that later became hidden or repressed (Lundby, 1998; White, 2006). For a transgender woman, the ability or talent to be a woman may fall into this category.

For some transgender people, it seems that the medical treatment process also affects the development of identity and self-understanding. How one experiences oneself can be different, depending on whether one has completed the treatment or not. Generally, it seems that physical considerations mean a lot (Davy, 2011). Marianne (50) finished her treatment three years ago and describes the end of the treatment process as finally being able to live as the woman she had always been: 'I'm so satisfied with my body, and especially with my boobs. I always wear low neck blouses to show a bit of them.' For Siri, who is undergoing medical evaluation, the body image seems to be different. She has a lot of dark hair all over her body, which prevents her from dressing as she wants. Siri states that:

It's even worse in summertime ... I'm longing for the transsexual diagnosis. Then I can cover the expenses of removing this hated hair. Boobs are important as well. I don't like wearing an artificial limb ... I don't think it's natural. 
These examples reflect the perception about a permanent connection between the person you are and your body experience and body image (Almås \& Benestad, 2017; Davy, 2011; Serano, 2016).

Karin (44) and Berit (34) still live as males, hiding their female identity. They are struggling in ways that are both different and similar. They try to navigate in a hostile environment but do not struggle with identity issues. Berit has always known that she is a woman but chooses not to show it. For 10 years she has lived with her girlfriend Randi and knows that if she lets her female side come through, she will lose both Randi and their joint network and future. 'I've stopped cross-dressing as well ... when I wear women's clothes, the longing becomes too strong. I repress myself out of consideration for Randi. That's what I want just now.' By choosing to maintain her family life, she has to make difficult choices about how to present herself to others. Berit and Karin have the nonphysical aspect in common. They choose to dress in a gender-neutral way and look into mirrors as rarely as possible. Whereas Berit has made a conscious choice to live as a male for now, Karin faces a different struggle. When responding to the question of identity, she says:

\footnotetext{
I feel like nobody ... in no man's land ... always thinking about what's right or wrong. I have a divided dream: On the one hand, I wish to live a "normal" life with my wife and children. On the other hand, I want to live as a woman all the time. I'm stuck between and can't decide what to do.
}

The statements of Karin and Berit may be seen as an expression of longing to be themselves, but they are trapped in the expectations of those in their surroundings (Benestad \& Almås, 2001; Moen, 2008; Arntzen \& Kahrs, 2013).

Shame is a recurring theme in the participants' narratives. For some, it is more pronounced than for others. In anthropology, the concept of 'shame' tends to be connected to the concept of 'honour', the interaction between the terms making them define each other (Melhuus, 2002). The implication of this is that if the concepts of honour and shame are part of the same social phenomena, there is no shame without honour (Arntzen \& Kahrs, 2013; Melhuus, 2002). With regard to gender, such a perspective could be understood as expectations about what is feminine and masculine. The experience of shame can be linked to the failure to meet expectations, which are connected to culture and the frame of reference (Frønes, 2002). The frame of reference links expectations to the understanding of what is feminine and masculine and the culturally defined honour of the gender roles. Our culture is basically guided by traditional views, which means that one has to adapt one's gender role to the rules of society (Butler, 2006). Shame is an abstract concept rooted in cognitive and emotional 
processes. When it is profound and all-consuming, as in the case of Karin, who is paralysed and unable to move on, one can imagine that she feels trapped in an emotional game in which the fear of other people's disgust plays an important role. This is also an issue discussed by Isaksen (2002).

For transgender people, shame may represent an additional burden. All the participants in this study experienced feelings of shame with regard to their gender challenges. The feeling of shame was less evident for participants who had acknowledged their gender identity, for themselves and in relation to others. Berit and Karin recognise having a female identity, but they have both decided to live as males because of the expectations of those in their surroundings. However, whereas Berit seems unruffled by continuing to live as a male, Karin is open about her feelings and speaks about her shame. She has seen a therapist for a year and relates that shame has been a key subject in their conversations. 'Things have improved since the therapy. If somebody should discover it now, I don't think it will be a catastrophe.' One can use shame to suppress one's own identity, letting oneself be guided by shame, as Berit does. The stories of Berit and Karin show that shame prevents them from expressing their female identity and developing their self-understanding as women. It seems that shame influences their self-understanding and that their belonging to the female gender is suppressed out of consideration for others in their environment. This is in accordance with theories of self-understanding (Henriksen \& Vetlesen, 2006; Røkenes \& Hanssen, 2012). For Karin, concern for both family and colleagues is important, while for Berit the relationship with her partner is essential. However, to keep undermining oneself forever may seem hopeless. Sooner or later, one will be confronted by one's true self. According to Allgeier and Allgeier (2000) and Almås and Benestad (2017), the awareness of belonging to a gender becomes well developed between the ages of three and five. People who conceive themselves females but live in a male body show that gender identity is an inherent quality that sooner or later will emerge and reinforce the understanding of one's gender (Almås \& Benestad, 2017). This is one of several human traits that is possible to suppress for parts of one's life, but sooner or later it will rise to the surface (Cullberg, 2008). This may be compared to sexual orientation or sexual arousal patterns, which are also to be understood as inherent aspects that will sooner or later manifest themselves, although obviously in different ways (Langfeldt, 1998). This view may be disputed, but it is supported by the participants' narratives. Ingrid (60) talks about her first memories, stating:

I already knew before I started school. In the neighbourhood there was a girl who was the same age as me. I looked at her clothes and hair. I didn't 
understand why I wasn't a girl, but thought that I would be when I grew up. I was so stupid and naïve. However, I knew that I couldn't talk to my mother about it.

\section{"Coming out"}

In this article, the term 'coming out' refers to recognising one's gender identity and being honest about it with oneself and others (Arcelus \& Bouman, 2018). In particular, Ingrid and Marianne are clear about how their female identity had to be revealed to those in their surroundings. At that time, they were adults of 50 and 45, respectively, and had lived in the closet their entire lives. Marianne states that:

It was in 2002. I couldn't stand it anymore. I dressed as a woman and went to work. Nobody knew anything. I think they got a shock. It was a relief, but at work I got lot a trouble afterwards ...

It is certainly unusual that someone just decides one day to go to work dressed in the clothes of a different gender than the one they presented themselves as belonging to the day before. Rather than coming out, this may be a sign of desperation. This way of trying to get gender affirmation (Benestad \& Almås, 2001; Hines, 2007; Wilchins, 2006) has caused Marianne many problems, including losing her job.

Alcohol or drug problems are not unusual for people struggling with identity issues (Semb et al., 2016). Ingrid has had a drinking problem throughout her life and has undergone detoxification treatment and therapy several times. She is well now and relates what happened some years ago, stating that Ten years ago, I was hospitalised again. I suffered a complete breakdown. I went to the doctor and told him everything ... I just had to get it out...'

Ingrid has been sober since coming out and the beginning of her gender affirmative process. 'I think I drank to forget who I was', she says. Marianne states that she also had a problem with alcohol for several years, but this is not a part of her life anymore. These examples show that some transgender people may have additional problems and that these problems may lessen or disappear as soon as one is able to accept being the person one actually is. According to the literature, the disappearance of mental problems once people are able to express themselves is not unusual. This is an important point that is often ignored in psychology and psychiatry, with people being refused hormones and surgery because they have stress-induced problems (Hausman, 2006; The Norwegian Health Directorate, 2015; Van der Ros, 2016).

As mentioned, Karin and Berit still have not come out. When one is trying to manage gender and identity in a different way as an adult compared to earlier 
in life, both social reactions and bodily challenges may cause further stress in the treatment process (Almås \& Benestad, 2001; Benestad, 2004; The Norwegian Health Directorate, 2015). Marianne, Ingrid and Turid have experienced this in different ways. For Marianne, the social part has been the most difficult. She lost her job and most of her social network. Three years ago, she and her girlfriend moved to a new place and tried to establish a new life. This is challenging at such a mature age, regardless of whether you have an identity issue. Still, Marianne is happy to finally live like the woman she has always been. She is also satisfied with the results of her bodily changes, and unless she reveals the truth herself nobody will know that this is a woman who has lived the greater part of her life as a male.

The greatest challenge for Ingrid and Turid has been the bodily process. Socially, they have been able to maintain most of their networks. Their relationships with their children are good, and they still live with the same women they married before the transformation process. The bodily effect of hormonal treatment has not met the expectations for either of them. The reason for this is that they were both adults when starting the treatment; Ingrid was 50 and Turid was 48. Accordingly, the doses of hormones they receive are considerable smaller than what younger people are given, which among other things means that breasts cannot be developed. Ingrid, who is now 60 years old, has finished her gender treatment. She has received breast surgery and says 'When I didn't do it years ago, I've got to be thankful for what I've got now. It isn't the real stuff, but better than nothing.' Today, Ingrid looks like a dignified middle-aged woman, while Turid has an androgynous look. She is very pleased about finally coming out and says she feels secure about the person she is. Dayv (2011) details similar stories about trans women's body changes.

Of the participants in this study, Siri is the youngest. She is 24 and came out three years ago. As mentioned, she has experienced bodily challenges, but with adequate treatment these will become more manageable in the long run. 'I just want to be myself', she says. There are too few participants in this study to reveal differences between younger and older transgender women. However, by interpreting Siri's narrative in the light of a similar study by Sally Hines (2007), one may suggest that younger people go through a more comfortable process after coming out. There are two main reasons for this (Roen, 2011). First, the body is more open to medical treatment at a younger age, which increases the desired effect of the treatment. This naturally implies a healthy starting point and a greater ability to endure hormonal treatment. Second, younger people's social networks are probably not so deeply rooted as those of older people. The 
younger you are, the less chance that established relationships have been formed, especially those involving regular partners and work.

Hines (2007) points out that conditions other than physical and social factors are beneficial in the process of coming out and the subsequent treatment of young transgender people. For example, the increasing presence of international and national organisations for transsexuals urges political authorities to support demands for medical treatment. These organisations rely on different kinds of professional knowledge, such as psychology and sexology, to disseminate knowledge and influence attitudes. This effort contributes to more knowledge about the transgender phenomenon in society. Younger transgender people also have other advantages that older people did not enjoy 30 or 40 years ago. One important factor is that access to the Internet enables people to meet other people in similar situations and thus create networks (Hines, 2007). Her experience with Internet networks was the reason Siri dared to come out. For Ingrid, Turid and Marianne, the reality was quite different. Ingrid states that 'The papers writing about Christine Jorgensen are burnt into my mind. At that point I became sure that something was wrong with me. But I was nearly thirty when I first heard the word transsexual.'

With regard to the bodily process, both Marianne and Ingrid are satisfied with their results and feel like it is a 'coming home'. In their reflections of 'the transgender journey', Aizura (2012) and Lykke (2010) also discuss this aspect. They refer to America's first transsexual woman, Christine Jorgenson, and other transgender women for whom the term 'home' has double significance. This is because many choose to undertake the journey through surgery before returning home as the woman or man they feel like. This illustrates that a permanent connection between person and body experience helps to create identity (Almås \& Benestad, 2017; Aizura, 2012). Marianne and Ingrid have both finished their gender-confirming treatment and feel like real women.

\section{Belonging}

In this study, four of the participants belong to the female gender. The other two participants feel like females but prefer to live as males. The aspect of belonging, which here refers to gender belonging, concerns an individual's experience of belonging to a category. Depending on one's surroundings, belonging can be confirmed in different ways. One can experience that he/she belongs to the female or male gender, whereas those in one's surroundings respond to the feminine or masculine characteristics. The term belonging can to some extent be included in the notion of identity. The feeling of gender belonging is usually related to identity and social relations (Almås \& Benestad, 
2017). However, more detailed descriptions may provide further knowledge and a better understanding about the transgender phenomenon. Therefore, the authors chose to take a closer look at the belonging perspective and see if the empirical information could facilitate a deeper understanding. Belonging can be considered a part of one's personal existential philosophy as well; to know who you are and how to become a person and social individual can be seen as one of the most imperative challenges in life (Aronsen, 2002).

The term gender belonging is connected to how gender is confirmed in human life. It can be described as feelings created through words and actions that are supportive and inclusive. Gender identity is an individual's internal gender experience. Characteristics such as bodily gender, body image and patterns of sex can also reflect a complete understanding of the meaning of gender belonging (Benestad, 2004). Belonging can be considered a fundamental human need (Karlsen, 2012). An established belonging reflects the correlation between our understanding of ourselves and how we are being understood by those in our surroundings. Gender belonging may occur in this interaction process (Almås \& Benestad, 2017). When a male body has a female identity, it cannot necessarily be understood and confirmed by others. This may complicate the discovery of belonging, both with regard to one's own body and one's surroundings. In such cases, one may discover a lack of correlation between the internal and external systems, and safe gender belonging becomes impossible. Siri provides an example, stating that 'I'm so tired of people who say "he" all the time! Last summer I met a Swedish boy who wondered if Siri is a boy's name in Norway.' This is an example of how the use of nouns may influence belonging and gender identity. The use of the 'right' noun clearly affects one's ability to feel recognised as a certain gender. In social interactions, the use of the 'wrong' noun may create formidable barriers (Ansara, 2010; McLemore, 2015).

Marianne looks very feminine, and it is impossible to tell that she has lived most of her life in a male body. She describes the problems connected to belonging that she experienced earlier in her life:

In the beginning I understand that it was difficult for family and friends to call me Marianne. But still, after several years, most of them say "he" and "Mats" when talking about me. I think it's because they want to be nasty! In any case that's how I feel. Therefore it was better to move far away and start a new life where no one knew me ....

The examples of Siri and Marianne reflect different challenges related to belonging and show that gender identity as a confirmed condition not only 
involves visible and external factors but can also be a result of the cultural and social context (Moen, 2008). However, it seems easier to achieve gender identity confirmation following surgery and hormonal treatment. Marianne has no difficulties being confirmed as a woman in her new environment. She describes herself as happily connected to other transgender women around her age. She is somewhat taller than the average woman, but she is slim and never had much body hair. The beard has been removed by laser treatment, and Marianne now has her own hair and does not need a wig. Her voice does not betray her because of treatment by a speech therapist. Siri is being evaluated for treatment, and even if she uses makeup and has a feminine hair style, her masculine body still 'betrays her'. The fact that surgery and hormonal treatment are required to achieve gender confirmation is also emphasised in Hines' (2007) research. Most of the participants in her studies stress the significance of hormonal and/or surgical treatment as a condition for well-being and selfconfidence, both in a physical and mental sense.

\section{Belonging connected to "born in the wrong body"}

Being a transgender person is often defined as being born in 'the wrong body'. To achieve a sense of belonging may also be a challenge when linguistic, social and medical constructions tend to reflect unusual phenomena that are not recognisable to those responsible for the constructions. The consequences of such thinking could be a simplification of the relationship between body and gender, based on anatomical body and dualistic gender theory (Hausman, 2006; Ekings \& King, 1996). The psychiatric diagnosis F64.0 in ICD-10 (World Health Organization, 2016) relies on the term 'transsexualism' and describes this as people 'feeling like the opposite sex'. The authors believe one consequence of this is that the medical perspective and technology to a large extent control the understanding of transgender people and that the body has to be adjusted to match the traditional gender thinking. In this way, the understanding of being born in 'the wrong body' is maintained. Siri states that:

I think it's rubbish to say that someone is born in the wrong body. I am a girl; it isn't only what I feel like. I don't think that my body is disgusting. I'm born with my body, and I have to make the best of it.

Siri's reflections call to mind the philosopher Merleau-Ponty's statement 'I am not in front of my body, I am in my body, I am my body'. This statement reflects how the meaning of human existence can be understood through the body's power of being-in-world (Rendtorff, 2002).

In Hines' study (2007), several participants view the term 'wrong body' as a cliché with which they do not feel comfortable and think that gender belonging 
ought to be seen as a considerably more nuanced and complicated process. The empirical findings in both the current study and Hines' research show that gender identity is primarily a cognitive and emotional condition and not a feeling of being born into or confined to 'the wrong body'. However, it seems like the diagnostication and treatment of transgender people are dominated by this perspective; one must have the F64.0 diagnosis of transsexualism in order to receive genital surgery in Norway (Van der Ros, 2016; Oslo University Hospital, 2018). The authors believe that this may be a result of the culture's binary gender thinking and the idea that genitals are the primary sign of gender belonging. According to the participants in this study, some members of the transgender community in Norway claim that being a transsexual implies a desire to complete hormonal and surgical treatment because one feels exclusively like a women or a man. As non-transsexuals, the authors will not reject this opinion, but it seems that even people who define themselves as transsexuals in some cases do not want genital surgery. Siri states that 'I'm not sure if I want genital surgery ... I've heard about people who are not satisfied with the result. Maybe if I once get enough money, I will go abroad to fix it ...'

This statement seems to indicate that there is an element of uncertainty connected to genital surgery procedures in Norway. Neither general attitudes towards transgender people nor medical priorities are helpful in broadening understanding in this area, which clearly requires further knowledge relating to sexual health and sexual rights (Graugaard et al., 2006; Moen, 2008; Molander, 1996; Ministry of Children and Equality, 2018) in general and to people who define themselves as transsexuals in particular.

To some transgender people it may be a challenge if the image in the mirror does not reflect the inner identity and belonging. Siri, who considers her beard the greatest challenge, says that it takes her several hours every morning to prepare her face before going to work. Ingrid, who finished her treatment 10 years ago, reflects that:

I couldn't stand my body, and in particular the genitals ... Luckily, I now have got things fixed ... On the other hand, after surgery I feel like a bluff. Nothing is real - not creation, but manipulation. Now and then I struggle with such thoughts. However, there are many "real" women who have manipulated their bodies as well ...

The above examples illustrate that the body can be manipulated to make it correspond to the experienced identity. To some transgender people, changing the body image may be essential to achieve gender confirmation (Benestad, 2004). Accordingly, what is feminine is debatable, as is the question of what 
characterises a woman. Some people think that transgender women overcompensate with excessively feminine behaviour (Hines, 2007). Both the current study and Hines' (2007) research show that transgender women cannot be subject to generalisations in this respect. The participants in the current study want to live and express themselves as 'ordinary' women. None of them exaggerate or invent feminine manners. 'That is what transvestites do', say Marianne and Turid.

\section{Belonging connected to the 'trans' term}

The term 'trans' can be discussed in relation to belonging, as the latter term refers to the experience of and need for belonging to a category (Almås \& Benestad, 2017). In this context, the categories are male or female and reflect the need to be the male or female you feel you are.

Some people with a gender identity that does not correspond to their body have a huge challenge in terms of being understood in the way they understand themselves. Some do not want to be understood or referred to as trans. For example, Siri does not like the term because she does not 'go from one condition to become something completely different'. Besides, the male and female genders dominate our culture, excluding a third category. With the possibility of medical technology changing physical gender, it seems that many transgender people have seen this possibility as the only solution to their emotional dilemma (Benestad \& Almås, 2001; Van der Ros, 2016).

The term trans can hardly be considered anything other than a phenomenon that exists between two extremes, an understanding that Siri, among others, does not feel comfortable with. Moreover, the term has been chosen in the absence of a more suitable term (Benestad, 2004). Despite the limitations of the term, some transgender people are comfortable with it, particularly adults. To Ingrid, Marianne and Turid, it felt like a relief to discover that a word could explain their challenges.

Over the last 20 years, transgender people have engaged in theoretical discussions about sex and gender. Interdisciplinary studies of transgender people not only reveal different meanings of gender terms but also reflect theoretical diversity (Benestad, 2004; Carroll, 2000; Hines, 2007; Dayv, 2011; Van der Ros, 2014; Serano, 2016). In Norway and the Nordic countries, queer theory does not reject the significance of gender and sexuality or downplay bodily and biological factors. Queer theory stresses the construction of gender, body and sexuality, which can only be understood in the context of language and culture (Moen, 2008; Almås \& Benestad, 2017; Van der Ros, 2016) with an emphasis on gender and sexuality alternatives, that is, pluralistic gender 
thinking. It stresses the significance of independent choice related to gender and sexuality. Untraditional living is not emphasised, but the possibility of leading such a life is still seen as important. Queer theories emphasise the diversity in how transgender people express themselves based on individual resources and differences (Benestad \& Almås, 2001). However, a pluralistic gender interpretation could be problematic when transgender people define themselves as males or females. For this reason, traditional binary gender thinking may be more suitable in explaining and understanding people with such an identity. The participants in this study have different goals and are in different stages of their transgendering process. It seems that the four who have come out are more able to develop an identity, self-understanding and belonging than the two who have not. To remain at an 'intermediary stage' makes the challenge of defining oneself even more difficult (Moen, 2008). However, there is also a need to view transgender narratives in a broader cultural context of life, embodiment and personhood (Aizura, 2012).

\section{Limitations}

The researchers have reflected on the fact that both personal and professional profiles shape the content of what we do. As cisgender people, the researchers could have ignored some details and signals in the participants' stories. One's own experiences may affect judgement, even though one should be selfreflective about one's own limited perspectives. A transgender researcher might have recruited more informants and received more detailed information. This could have impacted the results of the study. This study has a limited sample size; however, the narratives were rich in content, as all the women discussed the topics extensively and offered comprehensive descriptions about their experiences. This enabled us to relate the findings to other contexts. Only women wanted to participate in this study, and men's voices are therefore missing. A more comprehensive study in which transgender men are included is required.

\section{Conclusion}

The aim of this study was to gain a deeper understanding and more knowledge about the experience of transgender women regarding identity and selfunderstanding. The results of this study show that the participants exclusively have a female identity and belonging. Despite the female identity, two of the participants preferred to live as males out of consideration for those in their surroundings. The self-understanding of the informants found different 
expressions, depending on personality and life experiences. Whether or not one has come out of the closet seems important for both identity and selfunderstanding. The participants who have come out of the closet seem to feel more secure than those who have not. The feeling of belonging is in this case connected to gender identity and social relations. The more recognition they get from their social environment, the more it appears that the women in this study dare to be themselves. Gender identity may primarily be a cognitive and emotional condition and not a feeling of being born into or confined to 'the wrong body'.

\section{Implications for future research and practice}

The results of this study facilitate a deeper understanding of the different challenges for transgender women. There are several aspects regarding transgender women's and men's gender identity and self-understanding that are worth examining further. In addition, research may focus on the relationship with partners and close family, as well as on sexual identity and the experience of gender-confirming treatment.

The results of this study confirm the need for more knowledge among therapists and in society in general. Transgender people must be treated as individuals, both in society and in the primary and specialist health care services.

\section{References}

Aizura, A. Z. (2012). The persistence of transgender travel narratives. In T. T. Cotten (Ed.), Transgender migrations. The bodies, borders, and politics of transition (pp. 139-156). New York: Routledge.

Almås, E. (2004). Sex og sexologi [Sex and sexology]. Oslo: Universitetsforlaget.

Allgeier, E. R., \& Allgeier, A. R. (2000). Sexual interactions (5th ed.). Boston: Houghton Mifflin.

Almås, E., \& Benestad, E. E. P. (2017). Sexologi i praksis [Sexology in practice] (3rd ed.). Oslo: Universitetsforlaget.

Ansara, Y. G. (2010). Beyond cisgenderism: Counselling people with non-assigned gender identities. In L. Moon (Ed.), Counselling ideologies: Queer challenges to heteronormativity (pp. 167-200). Farnham, Surrey, UK: Ashgate Publishing Group.

Arcelus, J., \& Bouman, W. P. (2018). Language and terminology. In W. P. Bouman \& J. Arcelus (Eds.), The transgender handbook. A guide for transgender people, their families and professionals (pp. 1-12). New York: Nova Science Publishers.

Aronsen, H. (2002). Erik Gustaf Geier. Den personlige eksistensfilosofi [The personal philosophy of existence]. In R. Birkelund (Ed.), Eksistens og livsfilosofi [Existence and philosophy of life] (pp. 167-176). København: Gyldendal. 
Arntzen, M., \& Kahrs, K. (2013). De usynlige kjønn [The invisible sex]. Bergen: Fagbokforlaget.

Benestad, E. E. P. (2004). Transekjønn og diagnoser [Transgender and diagnoses]. Stavanger: Hertervig Forl. Stiftelsen Psykiatrisk Opplysning.

Benestad, E. E. P., \& Almås, E. (2001). Kjønn i bevegelse [Gender in motion]. Oslo: Universitetsforlaget.

Bouman, W. P., Claes, L., Brewin, N., Crawford, J. R., Millet, N., Fernandez-Aranda, F., \& Arcelus, J. (2017). Transgender and anxiety: A comparative study between transgender people and the general population. International Journal of Transgenderism, 18(1), 16-26. https://doi.org/10.1080/15532739.2016.1258352

Butler, J. (2006). Doing justice to someone: Sex reassignment and allegories of transsexuality. In S. W. Stryker (Ed.), The transgender studies reader (pp. 183193). New York: Routledge. https://doi.org/10.4324/9780203955055

Carroll, L., Gilroy, P. J., \& Ryan, J. (2000). Counselling transgendered, transsexual, and gender variant clients. Journal of Counselling and Development, 80(2), 131-139. https://doi.org/10.1002/j.1556-6678.2002.tb00175.x

Cullberg, J. (2008). Mennesker i krise og utvikling [People in crisis and development] (3rd ed.). Oslo: Universitetsforlaget.

Davy, Z. (2011). Recognizing transsexuals. Personal, political and medicolegal embodiment. New York: Routledge. https://doi.org/10.4324/9781315603919

Ekings, R., \& King, D. (1996). Blending genders: Social aspects of cross-dressing and sex-changing. London: Routledge. https://doi.org/10.4324/9780203201442

Frønes, I. (2002). Skam, skyld og ære i det moderne [Shame, guilt and honour in the modern]. In. T. Wyller (Ed.), Skam [Shame] (pp. 9-36). Bergen: Fagbokforlaget.

Førde, K. E. (2008). Den usynlige normen [The invisible norm]. Retrieved from http://forskning.no/kjonn-og-samfunn-homoseksualitet/2008/04/den-usynligenormen

Graugaard, C. (2001). Sexleksikon: Fra abe til aarestrup [Sex encyclopedia. From "abe" to "aastrup"]. Danmark: Rosinante Forlag.

Graugaard, C., Møhl, B., \& Hertoft, P. (2006). Krop, sykdom og seksualitet [Body, disease and sexuality]. In C. Grugaard, B. Møhl \& P. Hertoft (Eds.), Krop, sygdom og seksualitet [Body, disease and sexuality] (pp. 9-36). København: Hans Reitzels Forlag.

Hansen, T. M. (2001). Transsexualism and treatment in Norway [Transseksualitet og behandling i Norge]. Tidsskrift for den Norske Laegeforening, 121 (28), 33153316. Retrieved from http://www.tidsskriftet.no/index.php?seks_id=449592

Hausman, B. L. (2006). Body, technology, and gender in transsexual autobiographies. In S. W. Stryker (Ed.), The transgender studies reader (pp. 335-361). New York: Routledge. https://doi.org/10.4324/9780203955055

Henriksen, J.-O., \& Vetlesen, A. J. (2000). Nærhet og distanse: Grunnlag, verdier og etiske teorier $i$ arbeid med mennesker [Proximity and distance: Basis, values and ethical theories in human works] (2nd ed.). Oslo: Gyldendal Akademisk.

Hines, S. (2007). Transforming gender: Transgender practices of identity, intimacy and care. Bristol: Policy Press. https://doi.org/10.2307/j.ctt9qgpqw

Isaksen, L. W. (2002). Om angsten for de andres avsky [About the anxiety of others' disgust]. In T. Wyller (Ed.), Skam [Shame] (pp. 213-242). Bergen: Fagbokforlaget. 
Johannessen, E., Kokkersvold, E., \& Vedeler, L. (1994). Rådgivning: Tradisjoner, teoretiske perspektiver og praksis [Counseling: Traditions, theoretical perspectives and practice. Oslo: Universitetsforlaget.

Johansson, A. (2005). Narrativ teori och metod: Med livsberâttelsen i fokus [Narrative theory and method: With focus on the life story]. Lund: Studentlitteratur.

Karlsen, P. J. (2012). Psykologi [Psychology]. Oslo: Universitetsforlaget.

Kuper, L., Nussbaum, R., \& Mustanski, B. (2012). Exploring the diversity of gender and sexual orientation identities in an online sample of transgender individuals. Journal of Sex Research, 49 (2-3), pp. 244-254. https://doi.org/10.1080/00224499.2011.596954

Langfeldt, T. (1998). Sexologi [Sexology]. Oslo: Ad Notam Gyldendal.

Lundby, G. (1998). Historier og terapi: Om narrativer, konstruksjonisme og nyskriving av historier [Stories and therapy: About narratives, constructionism and rewriting of stories]. Oslo: Tano Ashehoug.

Lykke, N. (2010). Welcome to the conference transgender studies and theories - building up the field in a Nordic context. Graduate Journal of Social Science, 7(2), pp. 1924.

Malterud, K. (2011). Kvalitative metoder i medisinsk forskning: En innføring [Qualitative methods in medical research: An introduction] (3rd ed.). Oslo: Universitetsforlaget.

McLemore, K. A. (2015). Experiences with misgendering: Identity misclassification of transgender spectrum individuals. Self and Identity, 14(1), 51-74. https://doi.org/10.1080/15298868.2014.950691

Mead, G. H., Morris, C. W., Huebner, D. R., \& Joas, H. (2015). Mind, self and society (definitive ed.). Chicago: University of Chicago Press. https://doi.org/10.7208/chicago/9780226112879.001.0001

Melhuus, M. (2002). Hvilken skam uten ære? [What shame without honour?]. In T. Wyller (Ed.), Skam [Shame] (pp. 141-165). Bergen: Fagbokforlaget.

Ministry of Children and Equality (2018). The Equality and Anti-Discrimination Act, Oslo. Retrieved from https://lovdata.no/dokument/NLE/lov/2017-06-16-51

Moen, V. (2008). "Født i feil kropp": Narrativ tilnærming og opplevelser av transkjønnethet. ("Born in the wrong body": Narrative approach and experiences of transsexualism].Trondheim: NTNU.

Moen, V. (2010). Seksuell identitet hos mennesker med transseksualisme [Sexual identity among people with transsexualism]. Tidsskrift for psykisk helsearbeid, 7(4). pp. 303-311.

Molander, B. (1996). Kunskap i handling [Knowledge in doing]. Gøteborg, Fagbokforlaget Daidalos.

Monk, G. (2007). Narrativ terapi i praksis: Håbets arkæologi [Narrative therapy in practice: The archeology of hope]. København: Akademisk Forlag.

Rendtorff, J. D. (2002). Mourice Merleau-Ponty. Sansningens historicitet [The historicity of the sensation]. In R. Birkelund (Ed.), Eksistens og livsfilosofi [Existence and Philosophy of Life] (pp. 325-343). København: Gyldendal.

Riessman, C. K. (2008). Narrative methods for the human sciences. Los Angeles: Sage Publications.

Oslo University Hospital. (2018). Transseksualisme på Rikshospitalet. Behandlingsprogram [Transsexualism in Oslo University Hospital. Treatment 
Program]. Retrieved from https://oslo-

universitetssykehus.no/behandlinger/transseksualisme-pa-rikshospitalet

Roen, K. (2011). The discursive and clinical production of trans youth: Gender variant youth who seek puberty suppression. Psychology \& Sexuality, 2(1), 58-68. https://doi.org/10.1080/19419899.2011.536316

Røkenes, O. H., \& Hanssen, P. H. (2012). Bære eller briste. Kommunikasjon og relasjon $i$ arbeid med mennesker [Carry or burst. Communication and relationship in work with people] (3rd ed.). Bergen: Fagbokforlaget.

Sanger, T. (2010). Beyond gender and sexuality binaries in sociological theory: The case for transgender inclusion. In T. Sanger \& S. Hines (Eds.), Transgender identities. Towards a social analysis of gender diversity (pp. 259-276). New York: Routledge. https://doi.org/10.4324/9780203856147

Semb, R., Borg, M., \& Ness, O. (2016). Tilpasning eller tilbaketrekning? Tilhørighetsstrategier blant unge voksne med rus og psykiske problemer [Adaptation or withdrawal? Adaptation strategies among young adults with drug abuse and psychological problems]. Tidsskrift for velferdsforskning, Argang 19(3), 204-220.

Serano, J. (2016). Whipping girl - A transsexual woman on sexism and the scapegoating of femininity. Berkeley, CA: Seal Press.

Stryker, S., \& Whittle, S. (2006). The transgender studies reader. New York: Routledge. https://doi.org/10.4324/9780203955055

The Norwegian Health Directorate. (2015). Rapport: Rett til kjønn - helse til alle kjønn. Utredning av vilkår for endring av juridisk kjønn og organisering av helsetjenester for personer som opplever kjønnsinkongruens og kjønnsdysfori [Report: Right to gender - health of all sexes. Examination of conditions for the change of legal gender and organization of health services for persons experiencing gender incongruence and gender dysphoria]. Oslo: Helsedirektoratet.

Van der Ros, J. (2014). Når kjønn er et valg - Transpersoners inntreden i verden [When gender is a choice - transgenders' entry into the world]. Fontene Forskning, 1(7), 56-68.

Van der Ros, J. (2016). Den norske staten og transpersoner - Velferdsstatens og rettsstatens unnlatelsessynder. [Transgender people in Norway - Sins of omission in the welfare state and the rule of law]. Norsk Statsvitenskapelig Tidsskrift, 3(32), 264-289.

White, M. (2006). Narrativ praksis [Narrative practice]. København: Hans Reitzel.

Wilchins, R. A. (2006). What does it cost to tell the truth? In S.W. Stryker \& S. Whittle (Eds.), The transgender studies reader (pp. 547-551). New York: Routledge. https://doi.org/10.4324/9780203955055

Winzer, R., \& Bostrøm, G. (2007). Mental illness, suicidal thoughts and attempted suicide among homosexuals, bisexuals and transsexuals - Result from Swedish studies. Suicidology, 12(1), 10-13. $\quad$ Retrieved from http://www.med.uio.no/klinmed/forskning/sentre/nssf/tidsskrift/2007/nr1/Winzer. pdf

World Health Organization. (2016). F64.0: Transseksualisme [Transsexualism]. International statistical classification of diseases and related health problems (ICD10). Retrieved from http://apps.who.int/classifications/icd10/browsw/2016/en 